DOI: https:// 10.15407/kvt196.02.080

UDC 616.89-07-08(035):616-036.82:355.11:355.721

SHVETS A.V., DSc (Medicine), assistant professor, Head of research department of special medicine and psychophysiology of Research institute of military medicine, e-mail: shvetsandro@gmail.com Research Institute of Military Medicine of Ukrainian Military Medical Academy, 45/1, corp. 33, Moskovskaya st., Kyiv, 01015, Ukraine

\title{
PSYCHOMEDICAL INTERVENTION MODEL FOR SERVICEMEN BASED ON A STUDY OF MENTAL DISORDERS
}

Introduction. Many domestic and foreign experts work under the problem of mental health at combat environment in various aspects, however, a lot of unsolved questions regarding to psychomedical consequences of hybrid war in Ukraine still exist.

The purpose of the article - is to assem and to analyze the influence of various harmful factors in combat environment on the psychological status and mental health of military personnel and ex-combatants for development of psychomedical intervention model.

Materials and methods. The materials of research were based on the study of more than 200 servicemen in different conditions and health state using own and adopted questionnaires with further descriptive and multivariate exploratory technics of data analysis. Bibliosemantic, information-analytical, comparative analysis of domestic publication from the last 4 years have been done for summarizing the national experience regarding to psychological aftereffects of armed conflict in Ukraine.

Results. A retrospective summarizing of available information on the medical and psychological consequences of hybrid war relating to the characteristics of their aftereffects in recent years among military and demobilized persons has been performed. An assessment of stress factors impact at combat environment (physical, informational, organizational and anticipation) on military personnel participated in military conflict has been done. The specific features and structure of mental disorders in the military personnel, which were treated in hospital conditions have been revealed. The decision support model for reliable $(p<0.001)$ prediction further adjustment disorders after extreme conditions has been developed.

Conclusions. The greatest influence on the stress formation of combatants had "anticipation" factors as well as not much less pronounced "physical", "informational" and "organizational" environmental factors. Research permits to conclude that some of them significantly influence on the psycho-emotional state of military personnel and can be grouped into two main factors: the 1st-factor of negative future prediction and the 2nd-factor of negative impact of physical environment. The phenomenon of exaggerating of negative feelings

(c) SHVETS A.V., 2019 
among servicemen after the 4th-month impact of the stress factors has been discovered. The decision support model to predict further adjustment disorders (F43.2) after extreme conditions has been created for developing the Psychomedical Intervention Model in Ukrainian Armed Forces.

Keywords: psychomedical intervention model, decision support model, mental health, adjustment disorders, posttraumatic stress disorder, stress factors.

\section{INTRODUCTION}

Military conflict in the East of Ukraine creates thousands of people who continue military service or return into civil society after demobilization with numerous features of militarized consciousness that significantly affect the further development of society and country. The occurring events in combatzone can be characterized by high intensity, tension, transience. The occupational activity in these extreme conditions requires from servicemen to perform work at the limits of their capabilities, which, as usual, affects mental health.

The World Health Organization made enormous strides [1-5] in developing effective health care for most of the mental disorders and further improvements in treatments are likely thanks to advances in the understanding of brain functioning and psychosocial factors particularly in health promotion, prevention and treatment, rehabilitation and restoration of health etc. The relevance of this is understandable, since mental health was, is and will be an important social criterion of growing development and prosperity of the country and society; it greatly affects demographic situation, national security, processes and results of economic, social and cultural development. That is why a forward mental health care is very important in NATO-led operations (SANAGs 2564, 2565, 2566, 2568, 2569, 2573, 2548) and many problems of it are still in study now.

Features of posttraumatic stress disorder (PTSD) of foreign armies' combatants has been comprehensively described in [6]. For example, it was found that the prevalence of PTSD varies in different social groups [7]. PTSD manifestations were higher in those who did not have high education and repeatedly killed during hostilities. Also, the level of PTSD manifestation increased depending on the deployment duration (the PTSD presence in military personnel fluctuated from $9 \%$ to $31 \%$ of those who were in combat zone for more than a year), as well as their trauma characteristics [8]. PTSD manifestations were observed in $18.3 \%$ of those who were exposed to heavy weapons, and this figure among the wounded was $23.9 \%$. In 2013, the prevalence of PTSD and / or depression among war veterans in Iraq and Afghanistan was 20\%. A number of researchers point out that this figure is much higher, justifying this by concomitant diagnoses of brain trauma (19\% of veterans) which was not taking into account in the statistics of PTSD and other behavioral disorders. Among veterans of Iraq and Afghanistan, according to some studies, 39\% of ex-combatants had problems with alcohol abuse and 3\% drug use [8].

Unfortunately, there is no comprehensively summarizing information on relevant statistics of mental disorders and their observed effects among combatants and their families in available sources because of the high dynamics of situation in Ukraine. Furthermore, not only PTSD is the undesirable effect of combat stress, but also administrative and criminal offenses, suicide, violence in the family, addictive behaviors etc., which, at first, belong to the different areas of 
executive power, and secondly — some data are not fully presented (one by one) and out of the open access.

Many domestic and foreign experts work under the problem of mental health at combat environment in various aspects, however, a lot of unsolved questions regarding to psychomedical consequences of warfarein Ukraine are still exist.

The purpose of the article is assessment and analysis of influence of various harmful factors in combat environment on the psychological status and mental health of military personnel and ex-combatants for development of psychomedical intervention model.

\section{MATERIALS AND METHODS}

The materials of research were based on the study of more than 200 servicemen in different conditions and health state using own and adopted questionnaires with further descriptive and multivariate exploratory technics of data analysis.

The specially designed questionnaire, after examination by medical commission that confirmed their fitness to military service was filled in by 101 servicemen (20-30 years of old). The questionnaire was developed using an expert method. Ten combatants were invited upon their return from combat zone as experts who clarified the list and formulation of the questionnaire. As a result, there were formulated qualitative and quantitative measures of most important aspects of life in the combat environment. Evaluation of each stress factor was estimated on 19 questions (in \% of strength of human fillings).

Resembling examination of 101 servicemen (20-35 years of age) using specially designed questionnaire for study adjustment disorders at hospital condition among combatants was also performed [9]. This method can assess the impact of physiological stress (10 questions), hardiness (commitment, control and challenge) (12 questions), intrusion (8 questions), avoidance of military personnel (7 questions) in situations that occur at combat zone. Evaluation of each question was performed in 10-point scale (from min to max manifestation).

The analysis of general morbidity on mental and behavior disorders among military personnel of Ukrainian Armed Forces in 2008-2016 years has been performed using official statistical data from automated information system of MTFs medical reports.

All examinations were performed in accordance with ethical standards of the responsible committee and the Helsinki Declaration and have been approved by the Bioethics Commission of Ukrainian Military Medical Academy.

Bibliosemantic, information-analytical and comparative analysis of domestic publication from the last 4 years have been done for summarizing the national experience regarding to psychological aftereffects of armed conflict in Ukraine.

Statistical analysis was performed by methods of descriptive statistic, multivariate exploratory technics (multiple regression, factor and discriminant analysis) using software STATISTICA 6.0 (license \#AXX910A374605FA). 


\section{PROBLEM STATEMENT}

Features of mental and behavioral disorders among Ukrainian military personnel (background research).According to the analysis of open sources of the medical information, provided by Ministry of Health of Ukraine and Ministry of Defense, 5327 combatants needed the treatment due to mental disorders, and 4876 of them were suffering from stress disorders in the period from April 2014 to September 2015 [10]. Among them: acute stress reaction (59.3\%), PTSD $(13.3 \%)$ and adjustment disorder (19\%). Only $20.6 \%$ of soldiers could continue their military service after the treatment. The nosologic structure of hospitalized soldiers in 2014 showed that the majority of patients suffered from stress disorders $(84.1 \%)$; mental disorders caused by psychoactive substances was diagnosed in $3.8 \%$ cases. Organic mental disorders had $6.2 \%$ of combatants, and psychotic disorders $-2.5 \%$. Only $20.6 \%$ of servicemen could continue their military service after the treatment. Compared to 2014, in the first half of 2015 the percentage of soldiers, who were hospitalized due to stress disorders, reduced to $53.8 \%$. At the same time, the percentage of persons with mental and behavioral disorders caused by drug abuse (mainly alcohol) increased in 8 times and reached the level of $34.0 \%$.

From July 2014 to October 2016 Ukrainian scientists [11] found that mental and stress-related neurotic disorders were diagnosed in $37.5 \%$ of servicemen, than alcohol abuse $(25.6 \%)$, organic, including symptomatic mental disorders (24.6\%). Patients with schizophrenia amounted to $1.7 \%$, acute transient delusional disorders $-5.6 \%$, personality disorders $-1.3 \%$. Thus, since 2015 , the redistribution of mental disorders structure associated with addictive behavior has taken place.

Interesting results in 2014 were obtained from 96 combatants treated due to brain concussion, posttraumatic neuropathy, aggravation of chronic musculoskeletal diseases, the consequences of damaged limbs - defects of soft tissue and bone defects etc. [12]. In this study PTSD was combined mostly with the effects of different severity traumatic brain injury (TBI). Anxiety and depression scale (assessed by the HADS) were predominantly subclinical. 55\% of servicemen had elevated levels of peritraumatic dissociation. The results of E. Vartegh drawing test, along with high adaptability, have shown such trends as: a sense of imbalance, high anxiety and tension, the presence of fear, the need of "self-I" protecting and outside support. This study indicated that $67 \%$ of combatants presented a high adaptability. Researchers observed the desire to withstand for illness and fight for health. It may be explained as a key to positive outlook on disease prevention and posttraumatic growth. However, at the same time, military personnel could be characterized by strong tension and dissatisfaction with the current situation.

In $92 \%$ cases the fears and concerns were hold inside and were not a point of discussion with anybody [12]. However, the sharpness of negative emotions (anxiety, loneliness, fear of the future) leading to a state of helplessness, reduced ability to cope with obstacles and difficulties in problems solving (58\%), may demonstrate the need to protect and belonging to someone else or need for outside support. 
The experts of Ukrainian Research Institute of Social and Forensic Psychiatry of Ukrainian Ministry of Health [13] found that 33.3\% of mental disorders among hospitalized combatants defined by individual symptoms and did not reach the clinical level of mental illness. The main nosologies were presented as follows: organic emotionally labile [asthenic] disorder (F06.6) was detected in 6.8\%, postconcussional syndrome (F07.2) in 4.0\%, other personality and behavioral disorders due to physiological condition (F07.8) in 2.8\%, PTSD (F43.1) - in 22.5\%, adjustment disorder (F43.2) in 27.3\%, neurasthenia (F48.0) in 5.2\% of patients. Most cases of PTSD were often complicated by comorbidity with bipolar disorders, depression, disorders due to substance abuse, psychosis, personality disorders, and injuries to the formation of chronic pain. Despite the serious psychological circumstances, $30.4 \%$ of PTSD patient and $1.5 \%$ with adjustment disorder intend to return to their military units as soon as possible.

$25.1 \%$ of military personnel were unfit to military service due to mental disorders in 2015 [14]. Injuries and traumas were inherent to $16.7 \%$, cardiovascular system diseases $-15.4 \%$; diseases of nervous system $-11.6 \%$, and diseases of digestive system $-5.5 \%$.

In addition to this, the index of psychogenic casualties reached almost to $80 \%$ and was significantly higher than was before military conflict (almost in 3 times) in 2014-2015. 30-40\% of these cases were ended by transformation of psychological health (borderline) disorders into psychiatric nosology that significantly increased the number of discharges from military service $[15,16]$.

Features of mental and behavioral disorders among Ukrainian ex-combatants. During reintegration of demobilized people into civilian life there were studied 63 ATO participants with PTSD in comparing with a group of 17 people who had only psychological problems. It was concluded that high levels of state anxiety were a reaction to experienced stress (group $1-100.0 \%$, and group $2-88.2 \%$ ) while significantly high level of trait anxiety prevailed in patients who had PTSD according to both objective (at 93,7\% - 20,6 $\pm 2,3$ points) and subjective evaluation (at 90,5\% - 44,5 \pm $\pm 1,12$ points) [17]. Both groups of people felt equally strong presence of depression in group $1-85.7 \%$ (15.1 \pm 2.04 points $)$ and in group $2-64.7 \%(17 \pm 1.3$ points $)$.

The first manifestations of PTSD polymorphism as clinical features came out after 2-12 months (in average $8.68 \pm 0,46$ months) [18]. The authors pointed out the presence of two surges in forming of PTSD first signs: 4-6 months- in $37.5 \%$ and 11-12 months - in $46.4 \%$ of patients. Formation of the expanded symptoms was occurred within 1-12 months from manifestation of the first signs of this disorder. In $39.3 \%$ of servicemen forming PTSD lasted 2-3months. It could be noted that PTSD had a chronic or delayed type of progression in the time.

In other study [19] of 112 ex-combatants who participated at combat zone in 2014-2015 there were revealed additional peculiarities of PTSD. At first, it was a complex of mental and behavioral disorders associated with underground structures. Anxiety, emotional tension, feeling of danger, a sense of warm inflow or cold inside the abdomen, chest and head incased in situation of approaching to underground structures (basement, cellar, subway, etc.) and disappeared while moving inside these structures. This complex disorder was named as "underground syndrome" and it was observed in $26.2 \%$ of cases.Secondly, "combatant nyctophobia" was observed in $19.3 \%$ of cases and it was manifested by increased anxiety, emotional stress, obsessive thoughts about finding safeshelter, and violent martial reminiscences at night caused by the combat past.Thirdly, "combatant nyctosensibilisation" 
was observed in $34.5 \%$ of cases and manifested by heightened alertness, suspicion, a willingness to appropriate defensive reactions, hyperacusis, lower threshold of plosive-aggressive outbursts, etc., difficulty falling asleep at night (dyssomnia). Fourthly, the psychogenic agrypnia ("Sleep self-deprivation") was indicated in $13.8 \%$ of cases as obtrusive fear of the night artillery fire or reconnaissance and subversive groups attack. The most common clinical manifestations of these disorders were intense negative feelings of traumatic event (100.0\%) and sleep disorders $(100.0 \%)$, often there were registered nightmares for military subjects in patients (82.7\%), flashbacks (84.1\%) physiological (autonomic) hyperactivation (79.4\%), feelings of own future hopelessness beyond combat zone $(84.5 \%)$, reducing emotional blunting (76.6\%), efforts to avoid thoughts, feelings and conversations, reminiscent of the traumatic events $(73,9 \%)$, hypervigilance $(89,1 \%)$, irritation and outbursts of anger $(82,4 \%)$. It should be noted that $57.7 \%$ of patients had reduced interest in previous activities or lost it completely. Performed studies indicated that there were such significant psychogenic factors as vital threat, the first battle stress and stress factors of combat environment in PTSD genesis [19].

Influence of combat environment factors on combatants (own study). It is known the life-threatening conditions affect the person on such way that subjective feelings often go ahead from the appearance of objective signs of performance decline [20]. Within the framework of the environmental psychology [21], it is relevant to study the influence of certain conditions of combat environmental and occupational activities of servicemen on their feelings.

It should be noted that such influence of environmental factors on human begins from the time of waiting for extreme situations, when people are intensively preparing for future challenges. Then, this effect is greatly enhanced in combat environment conditions. The servicemen' psychological state transformation can be changed into normal or wicked way at the reintegration period depending on individual stress coping strategy and possible presence of damages and injuries. In this case, it is important to get information about the severity of the impact of certain combat environmental factors on the healthy troops that have to continue their duty in various environmental conditions.

To streamline the description of the results there have been identified the following such groups of factors of combat environments as "physical", "informational", "anticipation" (foresight) and "organizational". This factors' separation was quite arbitrary. The group of "physical" factors were associated with the direct damage on the soldiers. The group of "informational" factors reflected the effects of situation assessment and cause some negative feelings, such as fear. The impact of the combat situation caused in some soldiers associated sensations with the assessment of the consequences of this situation.

Anticipation function, which estimates the likelihood of possible effects on any events in human and predicts the consequences of their actions, has been assessed also. 


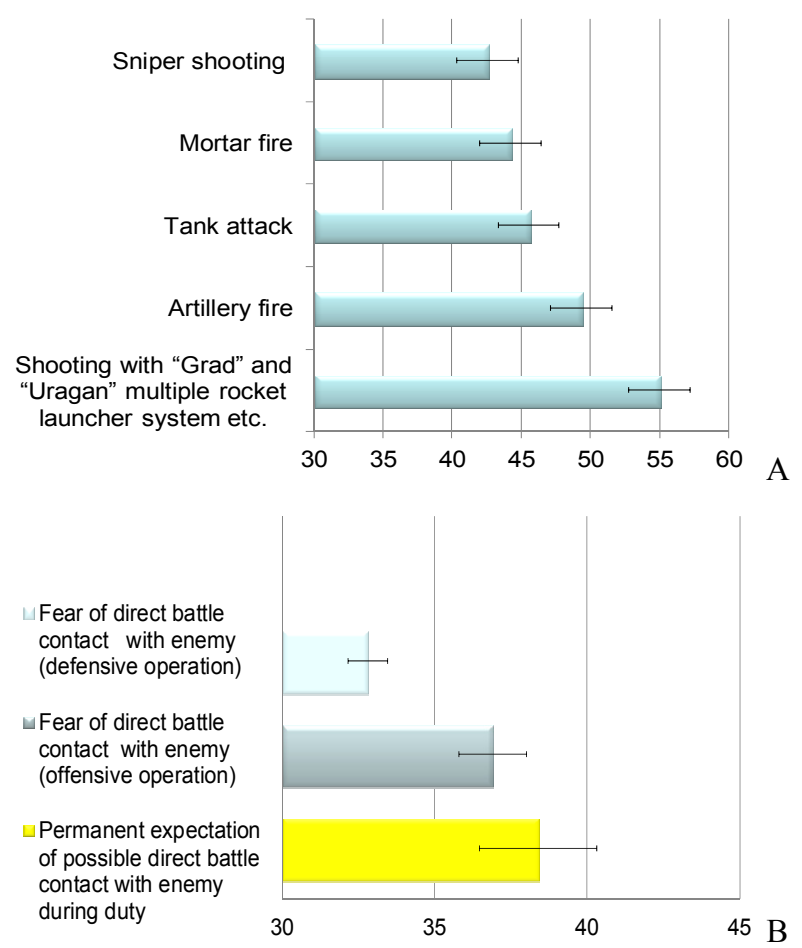

Fear to become a disabled war veteran

Death of battle friends

Fear of being captured

Fear of stepping on a land mine (blast mines)

Fear of riding on an anti-infantry high-explosive (butterfly explosion)

Friends wounding

Fear to be injured
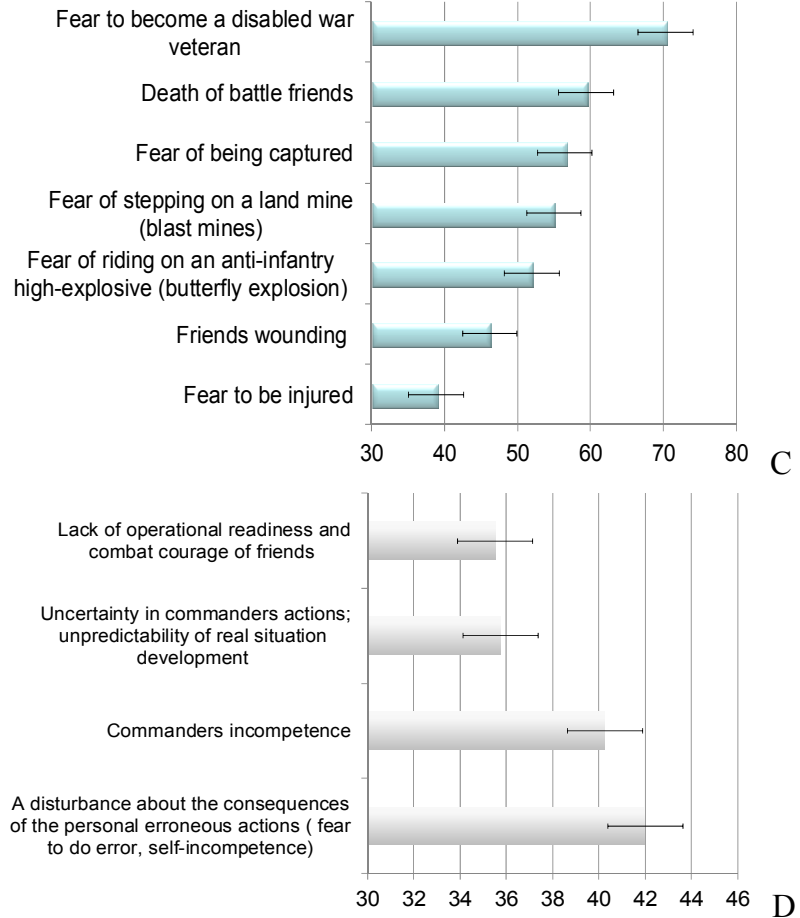

Fig 1. Influence of stress factors (estimated \% of strength of feelings at combat environment on military personnel. A — "Physical"; B — "Informational"; C — "Anticipation"; D — "Organizational". 
Shooting with "Grad" and "Uragan" multiple rocket launcher system etc $55 \%$ was the most influenced factor among all physical factors, and the least one was "sniper fire" factor. Feasibly, these experiences were derived due to the total area of destruction, since both reactive systems can cause damage to many soldiers and sniper activity had more individually oriented effect.

\section{FACTOR MODEL}

Perception of "informational" stress factors was estimated by respondents as follows (Fig. 1B). First of all, the level of influence of these factors was much lower than "physical" factors $(p<0.05)$. Secondly, the impression caused by the constant expectation of possible direct contact with the enemy in duty time was very strong and accompanied by negative feelings of anxiety (38\%) without observed circumstances of offensive or defensive operation.

The fact of direct contact with enemy infantry in the attack caused rather different feeling as fear. Expression of these emotions at the offensive operation reached to $37 \%$, in terms of defensive operation - about $33 \%$ indicated the presence of greater emotional stress among military personnel in the offensive operation. This difference is not so significant, possibly due to the fact that the phase of positional fighting was more probable. Although the impact of the "informational" and "anticipation" factors on psychological state are close enough, each of these factors had its own specifics.

Specific features of the "anticipation" factors were forecasting of their action negative consequences in a combat environment. They are shown in Fig. 1 B. As anticipated consequences can be very noticeable to human, the level of their impact on people was higher than "physical" factors. This indicates that the risk to be captured, the death of combat friends and especially fear of becoming disabled were the most significant in the soldiers' lives due to anticipation effects.

The fact that excess fear of possible injured comrades was more expressed comparing to their own is very interesting. This psychological effect can be generated by existing of military team cohesion, the propensity of people to sacrifice in terms of protecting the state integrity, military patriotism. Formulated thesis was confirmed by the fact that the assessment of stress-related feelings due to the wounded friends was higher in comparison to stress feeling related to own injuries.

The impact of various factors on the development of organizational stress was also estimated among the ATO members (Fig. 1 D). It should be emphasized that all organizational factors did not influence equally on the development of stress. Some of them had a quite distinct effect (a disturbance about the consequences of possible personal erroneous actions (fear to do error, selfincompetence), commanders' incompetence, uncertainty in commanders' actions; unpredictability of real situation development, lack of operational readiness and combat courage of friends).

The impact of these factors on functional state of military personnel could not be compared with the majority of the "anticipation" or "physical" factors components.

Thus, uncertainties in commanders' actions, unpredictability of a real situation are fairly close in content to the commanders' incompetence factor in terms of further events prediction under uncertainty. Military personnel were less disturbed by combat preparation training and morale of colleagues. 


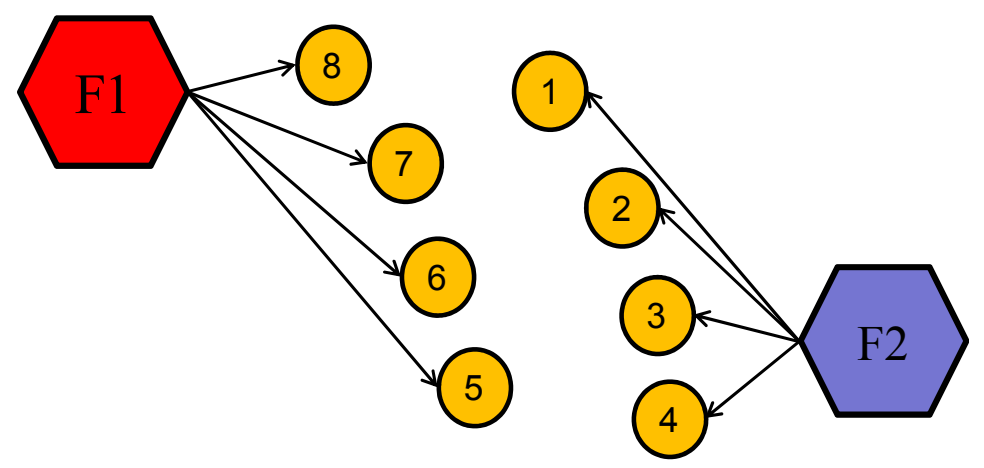

Fig. 2. The factor model influencing the development of adjustment disorders.1 - Shooting with "Grad" and "Uragan" multiple rocket launcher system etc., 2 - Mortar fire, 3 - Tank attack, 4 - Artillery shelling, $5-$ Fear of getting injured, $6-$ Fear of stepping on a land mine (blast mines), 7 - Fear of riding on an anti-infantry highexplosive (butterfly) mine, 8 - Fear to be captured.

Using factor analysis there were highlighted two factors that contribute adjustment disordersand explain $40 \%$ of total dispersion. As it is shown in Figure 2, there were the factor predicting the negative future effects (explaining 23\% of total dispersion) and the factor of negative impact of physical environment (explaining 17\% of total dispersion). The greatest influence on the formation of negative feelings among the environmental factors had "anticipation" factors as well as not much less pronounced "physical" factors. The analysis of those effect suggested that indirect impact on the soldiers' mind caused by anticipation of possible outcomes of events in some cases was more rapid than direct action of "physical" factors.

Of course, all manifestations of combat stress were not only depended on the intensity of warfare, but also on other external factors. Thus, according to research [19], critical external factors at the forefront were as follow: sleep deprivation (the average sleep duration was $2-4$ hours at the forefront in $71.1 \%$ of cases); poor living conditions (bunkers and trenches in remote locations of the main forces - tents type as Uniform sanitary barrack tent with a capacity of 35-40 people (dated by 1956 year) and heated winter tent with a capacity of 20-25 people (dated by 1968), adjusted buildings (barns, abandoned manufacturing plants, schools) were indicated by $65.3 \%$ of respondents); problems with personal hygiene (in $36.6 \%$ of respondents conditions for natural personal care needs were absent and often associated with life-threatening because of the risk of plant mines or to be targeted by a sniper).

The obtained results were reflected on official statistical data of morbidity. Since 2014, the indexes of mental and behavior disorders for all categories of servicemen have increased by almost in 4 times (officers - $22.4 \%$, contracted solders $28.4 \%$, conscripts $-20.4 \%$, which are significantly higher $(\mathrm{p} \leq 0,001)$ compared to 2013). The peak values were noted in 2015. In 2016, the morbidity of officers and conscripts decreased by almost 2 times (13.2\%o and $11.0 \%$ respectively); a slight decrease from $28.4 \%$ to $21.6 \%$ among contracted solders was noted. 


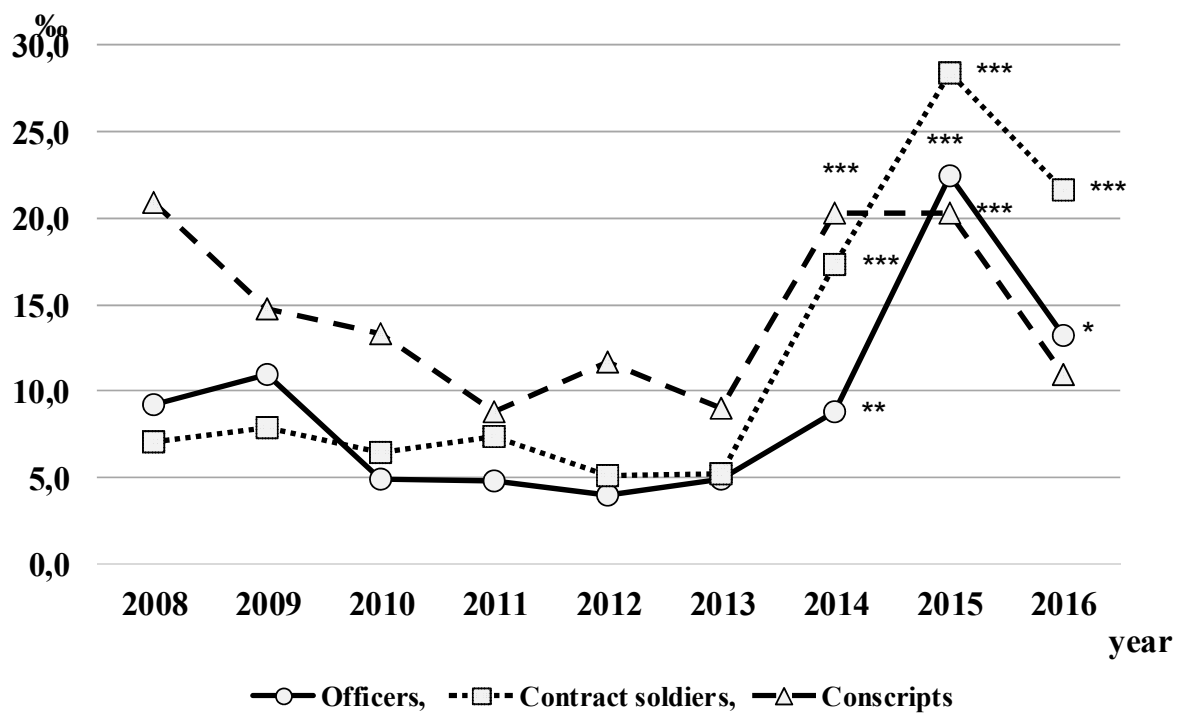

Fig. 3. Dynamics of general morbidity on mental and behavior disorders among military personnel of Ukrainian Armed Forces. *,**,*** — significant difference in overall general morbidity of mental and behavior disorders between 2013 year and 2014-2016 years according to Student's criterion corresponds to the levels $\mathrm{p}<0,05$, $\mathrm{p}<0,01$ and $\mathrm{p}<0,001$

This increase in overall morbidity was affected by a number of factors: the execution of combat missions in the combat area mostly by officers and contracted solders who had acute or delayed response on combat stress; low quality of mobilized servicemen selection.

\section{DISCRIMINANT MODEL OF MENTAL AND BEHAVIOR DISORDERS IN COMBATANTS}

Patterns of mental disorders in combatants. The next own study was based on using specially designed questionnaire for study adjustment disorders at hospital condition. All data corresponded to normal distribution, so the residual analysis of multiple regressions between the deployment time and different negative psychophysiological feelings after returning from armed conflict zone during rehabilitation in hospital conditions showed such phenomenon as overstressing negative feelings after 4 months of stress impact. Present troubles in feelings of the patients overstress in the future (Fig. 4). Therefore, this period is also important for further psychological rehabilitation at the outpatient level of care and for appropriate detection of depression due to overstressing negative feelings by combatants after 4 months from traumatic events.

Using a cluster analysis (criterion was $K$-means) of adjustment disorders characteristics including intrusive thoughts and anxious avoidance it was selected two groups of people who had significantly $(\mathrm{p}<0.001)$ different their levels. After that, forward stepwise discriminant analysis of the physiological stress characteristics and hardiness (commitment, control and challenge) of these selected groups has been used to figure out the most informative indicators of adjustment disorders due to stress. 


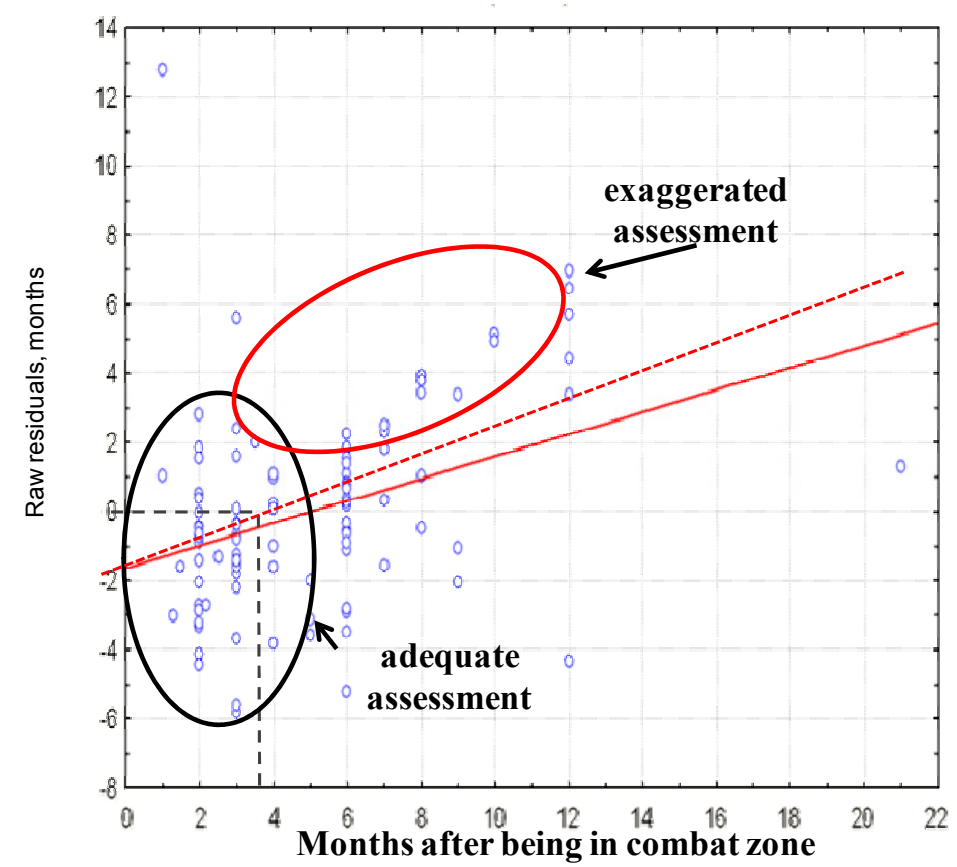

Fig. 4. Trends of enhancing negative feelings of military personnel after deployment in combat zone.

The resulting discriminant model has a high level of predictability $(\mathrm{p}<0.001)$ for classification of individuals by their dividing into two groups with different levels of adjustment disorders due to stress using such 3 items in 10-point scale (from min to max manifestation) as:

- Rate of cases of Startle Reflex after Unpredictable Situation (SR is a brainstem reflectory reaction that serves to protect vulnerable parts, such as the back or the neck and facilitates escape from sudden stimuli);

- Feeling to be Alone Among Friends (FAAF);

- Apathy to Work due to Problems (AWP). .

The decision support model for predicting of further adjustment disorders after extreme conditions is as follows:

$$
\begin{aligned}
& \mathrm{U} 1=-2,38+0,65 * \mathrm{SR}+0,43 * \mathrm{FAAF}+0,45 * \text { AWP; } \\
& \mathrm{U} 2=-7,47+1,20 * \mathrm{SR}+1,02 * \mathrm{FAAF}+1,03 * \text { AWP. }
\end{aligned}
$$

If $\mathrm{U} 1<\mathrm{U} 2-$ respondent belongs to "risk group" of possible further adjustment disorders after extreme conditions. This model allows to determine the identity of the subject to a group of "risk" with high probability — $98 \%(\mathrm{p}<0,001)$.

According to research performed in our Institute [22] the structure of mental disorders among military personnel who were treated in hospital conditions had certain characteristics. Volunteers and mobilized people had mental disorders in $41-42 \%$ of all cases (Fig. 5.A). 

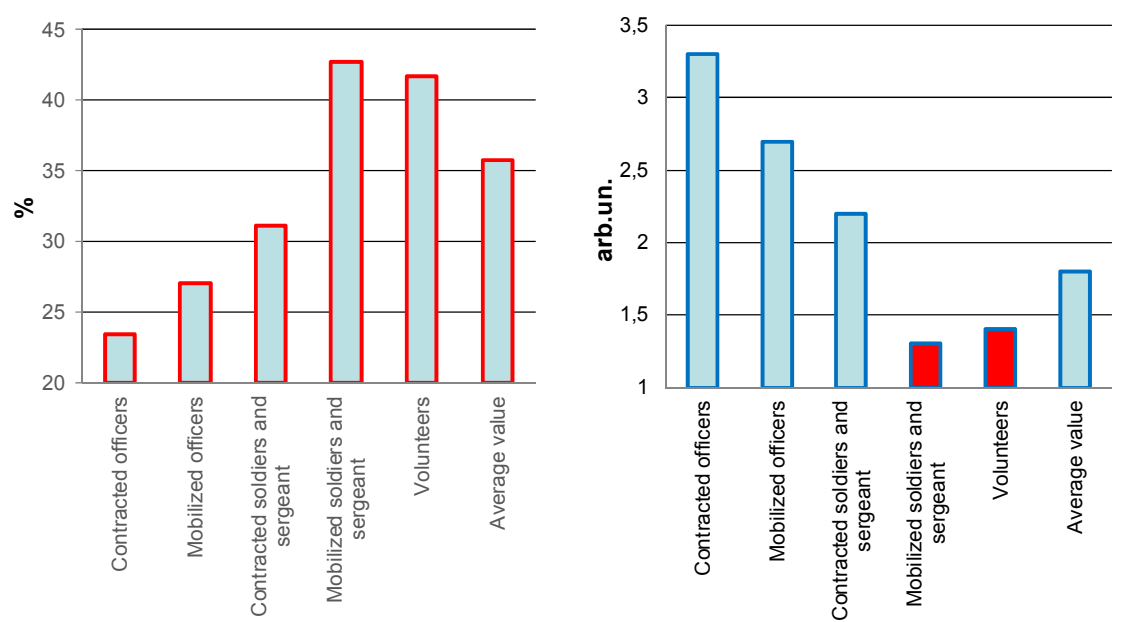

Fig. 5. Features of mental disorders among military personnel in hospital condition. A - with mental disorders, \%; B - the relation of personnel without mental disorders to the number of those who had them.

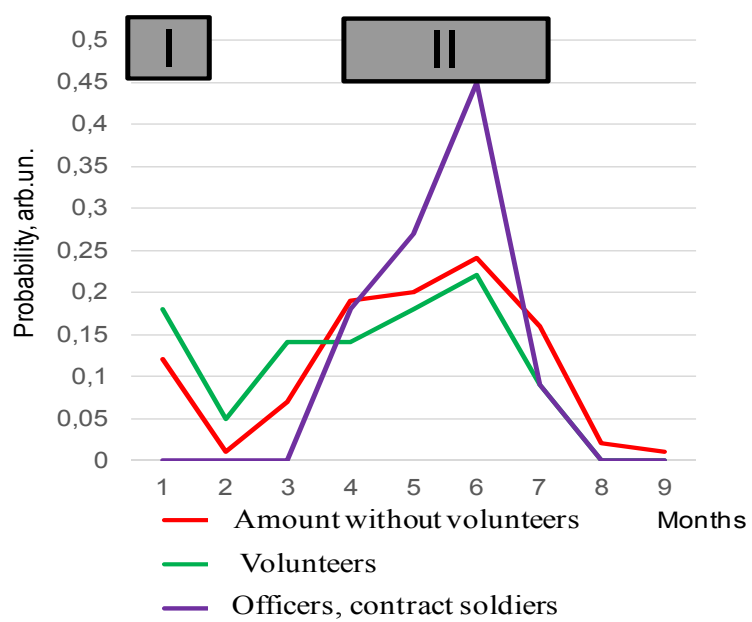

Fig. 6. Probability of mental disorders manifestation among warfare participants depending on the combat deployment time.

Moreover, among 13-14 volunteers, mobilized soldiers and sergeants nearly ten people had mental problems (the relations of personnel without mental disorders to the number of those who had it were 1:1,3 and 1:1,4; Fig. 5.B). Thus, the greatest manifestations of mental disorders were revealed in volunteers and mobilized people ( $71-77 \%$ of volunteers and mobilized soldiers and sergeants had mental problems) treated at hospital conditions in 2015.

The next stage of research was to find patterns of mental disorders in combatants depending on the deployment time in combat zone (Fig. 6).

The highest prevalence of mental disorders was found during the first and 6th months. It is important to note that officers and contract solders are the most vulnerable to the development of mental disorders while staying in combat zone around six months. 
Suicide problem.In our research [23] the frequency of suicide in Ukrainian Armed Forces was 7.2\% among all dead from March 2014 to January 2016 and this number was in 3 times higher in 2015 compared to $2014.42 .9 \%$ of suicide were committing in combat area, $57.1 \%$ were committing outside combat zone. $68.4 \%$ of suicides were committed at off-duty time. The largest number of suicides were committed by rank and file (65\%), sergeants committed suicide three times less $(22 \%) .11 \%$ of the suicides were officers and the lowest number was marked among civilian employees $(2 \%)$. Contracted military personnel could be characterized by more than half ( $55 \%$ ) suicide cases than mobilized solders ( $43 \%$ ). Most of the suicides among military personnel were committed as a result of firearms use (48 \%) or by hanging (41\%), much less by blasting agents and other ways (7\%).

The crucial difference in monthly indicators of suicides was observed in June and December, when these rates in 2015 were higher almost in two times comparing with 2014. The highest rates of suicides in May, July, September and November were common features in annual suicides structure at the period of 2014-2015.Thus, combatants had both relatively high rates of hetero- and auto-aggression behavior in combat area and in reintegration period after demobilization.

Our data was also corresponded with official statistics of Ukrainian Prosecutor General's Office [24]. From April 2014 to June 2016 servicemen had committed 259 suicides, 148 deaths were corded due to the accident, 121 premeditated murder, 111 violations of weapons and ammunition handling, 40 cases of safety measures violations and 112 were traffic accidents. It is important that the length of participation in military conflict had an excessive impact on the number of completed suicides. So, at the period from May 2015 to October $201640.2 \%$ of suicides were committed by those who took part in combat environment more than half a year, $34.1 \%$ of suicides were committed by those who took part in the ATO for 3-6 months [24].

\section{DEVELOPMENT OF THE PSYCHOMEDICAL INTERVENTION MODEL IN UKRAINIAN ARMED FORCES}

The resulting patterns should be taken into account for developing the psychomedical intervention model. For it proper understanding I proposed the definition of psychomedical aid as a complex of general health measures carried out by mental health professionals in the event of combat stress, its consequences, as well as in order to prevent the maximum reduction of traumatic situations impact on human health, support and/or rapid recovery mental health and psychophysiological functions of servicemen in order to achieve a high level of mental and physical ability (combat proficiency).

The developed Psychomedical intervention model was based on Mental Health Continuum Model accepted by NATO countries. In the first stages of mental disorders progression, the most important role in preserving mental health belongs to the commanders (Fig. 7).

Psychomedical aid should be carried out on all levels of medical evacuation (levels of medical care) in accordance with the main measures of care for acute stress reaction. When moving from one level to another, the capacity of care increases, while the number of individuals requiring psychomedical aid decreases. 


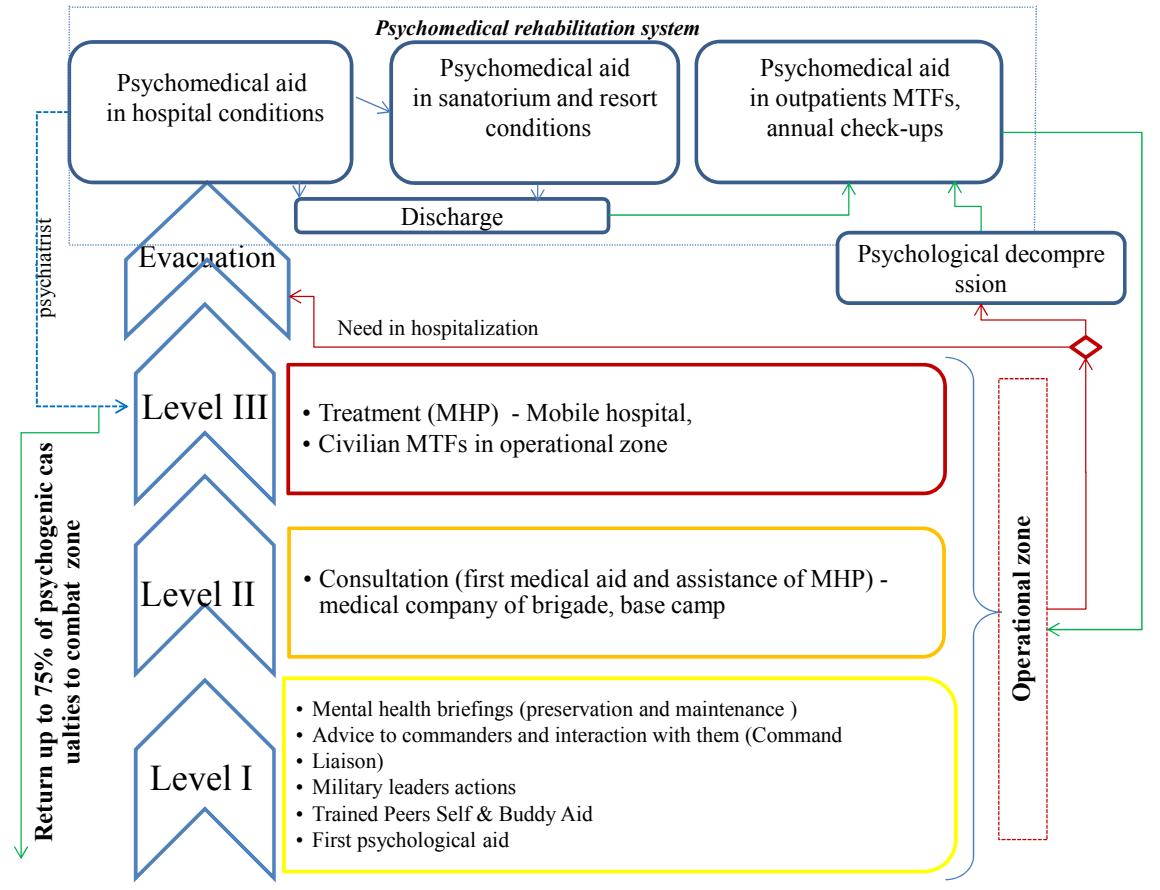

Fig. 7. Psychomedical intervention model in Ukrainian Armed Forces.

Level 1 support is the first line of support and includes leadership actions, self help and "buddy" support. This level normally occurs immediately following a potentially traumatic event and represents the most frequently in-demand level of support.

Level 2 support consists of a combination of medical and psychological assistance (provided by medical personnel of the military unit and mental health professionals).

And Level 3 support involves assessment and treatment services by mental health professionals.

After units' departure it is desirable to carry out measures of psychological decompression and the allocation of a group who need hospital medical care. I would like to note that due to the deployment of psychiatrists as reinforcement groups to the mobile hospitals, it was possible to significantly reduce $(75 \%$ of cases were returned to their duties) the movement of patients with mental and behavioral disorders to the higher level MTFs for psychomedical rehabilitation.

The organization of psychomedical aid is based on the principles of timeliness and accessibility, in accordance with the current level of scientific knowledge; necessity and adequacy of medical measures with minimal social and legal restrictions; consistency (implementation of medical and psychological assistance at the following levels with increasing capacity); continuity (the relationship between the stages of medical care with the capacity of medical and psychological aid, the maintenance of medical documentation); legality, humanity.

Psychomedical aid should not be performed only in military conflict context, it must be ensured in peacetime daily activities, which will ultimately contribute to maintaining the combat capability of the troops. 


\section{DISCUSSION}

In this study it was summarized available information on psychomedical consequences of warfare among military and demobilized persons through the last years. At the beginning of 2017 the situation has been slightly improved. At present time mental and behavioral disorders in the structure of therapeutic casualties among military personnel in combat zone were $4.9 \%$ at the beginning of $2017,77.5 \%$ of them were neurotic, stress-related and somatoform disorders.

These data, on the one hand, can be explained by decreasing intensity of armed conflict and psychogenic casualties in turn, implementation of preventive measures, better organization of psychomedical care in combat area, but on the other hand - by "stigma". For example, in studies [25] carried out on 450 servicemen (aged from 19 to 54 years) that took part in military conflict from August 2014 to March 2015, it was indicated that the most of people avoided any talks about traumatic events which negatively affected their emotional, psychological and physiological state, and they often resorted to such defense mechanism as "avoidance"(41.6\% of cases). Almost $36 \%$ of servicemen did not want "invasion" into their emotional sphere and they were not involved themselves emotionally in other situations. Some of ATO participants who were affected by psychological trauma displayed insomnia, excessive vigilance, exhaustion, escape into alcohol and others [25].

In this study at the first time the assessment of stress factors impact at combat environment (physical, informational, organizational and anticipation) on military personnel participated in military conflict has been done. The stability of working capacity is probably influenced by the expected threat, that is, the true or false prediction made by the person of some future collision with any dangerous situation and its assessment. The correlation of the anticipation factor with the manifestation of working capacity will be traced and also identified the conditions affecting it. Moreover, the decision support model to predict further adjustment disorders after extreme conditions has been created for developing the psychomedical intervention model in Ukrainian Armed Forces. The revealed 3 items including into discriminant model correspond with a new criteria of PTSD (ICD-11 for Mortality and Morbidity Statistics, class 6B40) and in addition give opportunity quantitatively predict further adjustment disorders after extreme condition. Presented research is not without flaws that are associated with the multidirectional vectors of the scientific searching of domestic authors. But, at the same time, an attempt was made to systematize them. Regarding own research, it contributed to the development of new pragmatic proposals to the military system of mental healthcare.

At the present time, we still don't have wide knowledge about the mechanisms of high reserves of working capacity manifested combat stress in extreme conditions. One can only assume that human reserves are hidden in the potentials of its redundancy (in the psychophysiological mechanisms of duplication of functions' regulation, in various forms of compensation).

Preliminary analysis of presented data allowed us to describe the set of the consequences of the trauma. These results may help for future reorientation of National mental health system, taking into account military needs. That's why the comprehensive National strategy for mental health care of veterans [26] 
should include continious systematic monitoring of mental health and risk assessment among military personnel, programs for prevention of drug addiction and alcohol abuse among soldiers and veterans, suicide prevention programs for military personnel etc.

\section{THE PERSPECTIVE FOR THE FURTHER SCIENTIFIC RESEARCH}

The research on recovery period is interesting because precisely in this period the psychophysiological mechanisms of compensation by regulatory functions are forming in the human body. For example, such complex concepts as tolerance, patience or resistance to the effects of stress factors, apparently, in some way are related to human serviceability, reliability and working capacity. And, if we understand this interaction, we can propose some measures aimed to overcoming the effects of stress.

\section{CONCLUSIONS}

The analysis of available information on psychomedical consequences of warfare among military and demobilized persons shows that 2015 was the year of the highest surge of mental disorders (adjustment disorders, drug abuse (mainly alcohol), suicides, hetero- and auto-aggression behavior etc.) and $25.1 \%$ of military personnel was unfit to military service due to mental health problems.

At the beginning of 2017 the situation has been slightly improved due to decreasing intensity of armed conflict and psychogenic casualties in turn, implementation of preventive measures, better organization of psychomedical care in combat area, and "stigma". The greatest influence on the stress formation of combatants had "anticipation" factors as well as not much less pronounced "physical", "informational" and "organizational" environmental factors. Research permits to conclude that some of them significantly influence on the psycho-emotional state of military personnel and can be grouped into two main factors: the $1^{\text {st }}$ - factor of negative future prediction and the $2^{\text {nd }}$ - factor of negative impact of physical environment.

The phenomenon of exaggerating of negative feelings among servicemen after the $4^{\text {th }}$-month impact of the stress factors has been discovered.

The decision support model to predict further adjustment disorders (F43.2) after extreme conditions has been proposed for developing the Psychomedical Intervention Model in Ukrainian Armed Forces.

\section{REFERENCES}

1. Comprehensive mental health action plan 2013-2020. Sixty-sixth World Health Assembly $66.8,2013: 27$.

2. Advocacy actions to promote human rights in mental health and related areas - WHO Quality Rights training to act, unite and empower for mental health (pilot version). Geneva: World Health Organization; 2017 (WHO/MSD/MHP/17.15). License: CC BY-NC-SA 3.0 IGO.

3. World Health Organization, Mental health and development: targeting people with mental health conditions as a vulnerable group. WHO, Geneva, 2010: 108.

4. World Health Organization, War Trauma Foundation and World Vision International. Psychological first aid: Guide for field workers. WHO, Geneva, 2011: 57

5. World Health Organization, Mental health action plan for Europe facing the challenges, building solutions. WHO, Helsinki Finland, 2005: 12. 
6. Richardson L.K., Frueh C., Acierno R. Prevalence Estimates of Combat-Related PTSD: A Critical Review. Australian \& New Zealand Journal of Psychiatry. 2010; 44 (1): 4-19.

7. Invisible wounds of war: psychological and cognitive injuries, their consequences, and services to assist recovery / Ed. by Terri Tanielian, L.H. Jaycox. Santa Monica: RAND Corporation, 2008: 453.

8. Ralevski E., Olivera-Figueroa L., Petrakis I. PTSD and comorbid AUD: a review of pharmacological and alternative treatment options. Subst Abuse Rehabil. 2014; 5: 25-36.

9. Shvets A.V. Improving the psychophysiological assessment methodology of combat conditions influence on the servicemen functional state. Military medicine of Ukraine. 2015; 2: 84-92. [in Ukrainian].

10. Inpatient treatment of the ATO participants / Ministry of Health of Ukraine; Ukrainian research Institute of social and forensic psychiatry and drug abuse. Kiev, 2016: 28. [in Ukrainian].

11. Zavalkoy U.M., Kutko I.I., Andreyko M.F., Yurchkova N.O. Structure of mental disorders in ATO participants (pilot study on clinical material of inpatient patients). Ukraine. Nation's health. 2016; 4/1 (41): 54-57. [in Ukrainian]

12. Stepanova N.M., Ladik-Brizgalova A.K., Boltonosov S.V., Sulimovska A.C. Sociodemographic and pathopsychological characteristics of post-traumatic mental disorders in combatants. Archives of psychiatry. 2015; 2 (81): 50-53. [in Ukrainian]

13. Pinchuk I.Ya, Pishel V.Ya, Polyviana M.Yu, Guzenko K.V, Ladik-Brizgalova A.K. Auto- and geteroagressive behavior in the structure of post-traumatic mental disorders at participants in the ATO. Archives of psychiatry. 2016;:3 (86): 5-11. [in Ukrainian].

14. Shevchuk R.V, Hanol M.V, Shimko V.A, Kiris O.P. Analysis of the work of military medical commissions in the special period / Medical support of the antiterrorist operation: scientificorganizational and medical-social aspects: a collection of scientific works / Ed. by Academicians of the National Academy of Sciences of Ukraine Tsymbaliuk VI. and SerdyukAM, State Institution of Informational Research Center "Priorities". 2016: 156-167. [in Ukrainian].

15. Druz O.V., Siropyatov O.G., Badyuk M.I. Improvement of treatment and rehabilitation of servicemen of Ukrainian Armed Forces with combat psychotrauma: Methodic recommendations. Kyiv: «Lesya», 2015: 52. [in Ukrainian].

16. Druz O.V., Chernenko I.O. Analysis of combat psychotrauma of participants in local combat operations Medical support of the antiterrorist operation: scientific-organizational and medicalsocial aspects: a collection of scientific works / Ed. by Academicians of the National Academy of Sciences of Ukraine Tsymbaliuk VI. and SerdyukAM, State Institution of Informational Research Center "Priorities". 2016:168-179. [in Ukrainian].

17. Mykhaylov B.V., Serdiuk O.I., Galachenko O.O., Galachenko V.V., Vashkite I.D. The course of post-traumatic stress disorder among the demobilized members of the antiterrorist operation, located on rehabilitation in sanatorium conditions. Ukrainskyi visnyk psykhonevrolohii. 2016; 2 (87): 69-73.

18. Pishel V.Ya., Polyviana M.Yu, Guzenko K.V. Clinical polymorphism of post-traumatic stress disorders at participants in the ATO. Archives of psychiatry. 2017; 1 (88): 75-76. [in Ukrainian].

19. Zavorotnyi V.I. Post-traumatic stress disorders in participants of the anti-terrorist operation (combat psychogenias, clinical-psychopathological characteristics). Ukrainskyi visnyk psykhonevrolohii. 2017; 1 (90): 48-50. [in Ukrainian].

20. Kalnish V.V., Pishnov G.Yu, Varivonchik D.V. Actual problems of psychophysiological state of combatants. Ukraine. Nation's health. 2016; 41 (4/1): 37-43. [in Ukrainian].

21. Gifford R. Environmental Psychology: Principles and Practice. University of Victoria. Fifth edition. Colville, WA: Optimal Books, 2014: 560.

22. Ivanov D.A., Rychka O.V. Psychoprophylactic measures before servicemen deployment to combat zone. Mental Health. 2015; 3 (48) - 4(49): 87-98. [in Russian].

23. Kazmirchuk A.P., Shvets A.V., Rychka O.V., Chaikovsky A.R. Suicides in Ukrainian Armed Forces: Analysis and Directions of Prevention. Problems of Military Health. 2017; Issue. 47: 310-319. [in Ukrainian] 
24. Pinchuk I.Ya., Petrichenko O.O., Kolodezhsky O.V., Zdorik I.F., Drevitska O.O. Morbidity and prevalence of mental and behavioral disorders as a result of the use of psychoactive substances among participants of the antiterrorist operation in Ukraine for the first half of 2016. Archives of psychiatry. 2016; 4 (87): 11-14. [in Ukrainian].

25. Pinchuk I.Ya., Yachniki U.V., Ladyk-Bryzgalova A.K., Bulakhova L.O. Psychological recovery and social integration of veterans in Ukraine. Archives of psychiatry. 2017; 1 (88): 6-10.

26. Stadnik I.V. Peculiarities of psychological trauma experience of combat operations participants in the antiterrorist operation. Psychology today: the view as a modern student: materials of the tenth international student scientific conf. Psychology, Brest, 2015 May, Pushkin Brest State University / Ed. by I.V. Shtotkova. Brest: BSU, 2015: 151-153. [in Russian].

Resieved 04.03.2019

\section{ЛИТЕРАТУРА}

1. Comprehensive mental health action plan 2013-2020. Sixty-sixth World Health Assembly 66.8, 2013: 27.

2. Advocacy actions to promote human rights in mental health and related areas - WHO Quality Rights training to act, unite and empower for mental health (pilot version). Geneva: World Health Organization; 2017 (WHO/MSD/MHP/17.15). License: CC BY-NC-SA 3.0 IGO.

3. World Health Organization, Mental health and development: targeting people with mental health conditions as a vulnerable group. WHO, Geneva, 2010: 108.

4. World Health Organization, War Trauma Foundation and World Vision International. Psychological first aid: Guide for field workers. WHO, Geneva, 2011: 57

5. World Health Organization, Mental health action plan for Europe facing the challenges, building solutions. WHO, Helsinki Finland, 2005: 12.

6. Richardson L.K., Frueh C., Acierno R. Prevalence Estimates of Combat-Related PTSD: A Critical Review. Australian \& New Zealand Journal of Psychiatry. 2010; 44 (1): 4-19.

7. Invisible wounds of war: psychological and cognitive injuries, their consequences, and services to assist recovery / Ed. by Terri Tanielian, L.H. Jaycox. Santa Monica: RAND Corporation, 2008: 453.

8. Ralevski E., Olivera-Figueroa L., Petrakis I. PTSD and comorbid AUD: a review of pharmacological and alternative treatment options. Subst Abuse Rehabil. 2014; 5: 25-36.

9. Швець А.В. Удосконалення методології психофізіологічної оцінки впливу бойових умов на функціональний стан військовослужбовців. Військова медицина Украӥни. 2015; 2: 84-92.

10. Стаціонарне лікування учасників АТО. - МОЗ України; УНДІ ССПН України. Київ, 2016: 28.

11. Завалко Ю.М. , Кутько І.І., Андрейко М.Ф., Єрчкова Н.О. Структура розладів психіки в учасників АТО (пілотне дослідження на клінічному матеріалі стаціонарних хворих). Україна. Здоров'я нащії. 2016; 4/1 (41): 54-57.

12. Степанова Н.М., Ладик-Бризгалова А.К., Болтоносов С.В., Сулімовська А.С. Соціодемографічна та патопсихологічна характеристика посттравматичних психічних порушень в учасників бойових дій. Архів психіатрії. 2015; 2 (81): 50-53.

13. Пінчук І.Я., Пішель В.Я., Полив'яна М.Ю., Гузенко К.В, Ладик-Бризгалова А.К. Ауто- та гетероагресивна поведінка у структурі посттравматичних психічних розладів у учасників АТО. Архів психіатрії. 2016; 3 (86): 6-11.

14. Шевчук Р.В., Ганоль М.В., Шимко В.А., Кіріс О.П. Аналіз роботи військоволікарських комісій в особливий період. Медичне забезпечення антитерористичної операції: науково-організаційні та медико-соціальні аспекти: збірник наукових праць / за заг. ред. академіків НАН України Цимбалюка B.I. та Сердюка А.М. К. : ДП НВЦ «Пріоритети», 2016: 156-167.

15. Друзь О.В., Сиропятов О.Г., Бадюк М.І. Удосконалення лікування та реабілітації військовослужбовців Збройних Сил України з бойовою психічною травмою : методичні рекомендації. МО України, НАМН, Укр. військово-медична акад. К. : Леся, 2015: 52. 
16. Друзь О.В., Черненко І.О. Аналіз бойової психічної травми в учасників локальних бойових дій. Медичне забезпечення антитерористичної операції: науковоорганізаційні та медико-соціальні аспекти : збірник наукових праць / за заг. ред. академіків НАН України Цимбалюка В.І. та Сердюка А.М. К. : ДП НВЦ «Пріоритети», 2016: 68-179

17. Mykhaylov B.V, Serdiuk O.I, Galachenko O.O, Galachenko V.V, Vashkite I.D. The course of post-traumatic stress disorder among the demobilized members of the antiterrorist operation, located on rehabilitation in sanatorium conditions. Украӥнський вісник психоневрологіï. 2016; T.24. Вип 2 (87): 69-73.

18. Пішель В.Я., Полив'яна М.Ю., Гузенко К.В. Клінічний поліморфізм посттравматичного стресового розладу в учасників бойових дій. Архів психіатрії. 2017; 1 (88): 75-76.

19. Zavorotnyi V.I. Post-traumatic stress disorders in participants of the anti-terrorist operation (combat psychogenias, clinical-psychopathological characteristics). Украӥнський вісник психоневрологіï. 2017; 1 (90): 48-50.

20. Кальниш В.В., Пишнов Г.Ю., Варивончик Д.В. Актуальні проблеми психофізіологічного стану учасників бойових дій. Україна. Здоров'я наиіï. 2016; № 4/1 (41): 37-43.

21. Gifford R. Environmental Psychology: Principles and Practice. University of Victoria. Fifth edition. Colville, WA: Optimal Books, 2014: 560.

22. Иванов Д.А., Рычка О.В. Психопрофилактические мероприятия среди военнослужащих, направляемых в зону боевых действий. Психічне здоров'я. 2015; 3 (48) - 4(49): 87-98.

23. Казмірчук А.П., Швець А.В., Ричка О.В., Чайковський А.Р. Суїциди в Збройних Силах України: аналіз та напрями їх запобігання. Проблеми військової охорони здоров'я. 2017; Вип. 47: 310-319.

24. Пінчук І.Я., Петриченко О.О., Колодєжний О.В., Здорик І.Ф., Древіцька О.О. Захворюваність і поширеність розладів психіки та поведінки внаслідок вживання психоактивних речовин серед учасників антитерористичної операції в україні за перше півріччя 2016 року. Архів психіатрії. 2016; 4 (87): 11-14.

25. Pinchuk I.Ya, Yachniki U.V., Ladyk-Bryzgalova A.K, Bulakhova L.O. Psychological recovery and social integration of veterans in Ukraine. Aрхів nсихіатріï. 2017; 1 (88): 6-10.

26. Стадник И.В. Особенности переживания психологической травмы участниками боевых действий антитеррористической операции. Психология сегодня: взгляд современного студента : сб. материалов десятой международной студенческой науч.практ. конф. по психологии, Брест, 14 мая 2015 г. Брест. гос. ун-т имени А.С. Пушкина; под общ. ред. И.В. Шматковой. Брест: БрГУ, 2015: 151-153.

Получено 04.03.2018 
Швець А.В., д-р мед. наук, старш. наук. співроб., начальник науково-дослідного відділу спеціальної медицини та психофізіології

НДІ проблем військової медицини, e-mail: shvetsandro@gmail.com

Українська військово-медична академія, вул. Московська, 45/1, корп. 33, м. Київ, 01015, Україна

\section{УДОСКОНАЛЕННЯ МОДЕЛІ МЕДИКО-ПСИХОЛОГІЧНОЇ ДОПОМОГИ ВІЙСЬКОВОСЛУЖБОВЦЯМ НА ОСНОВІ ДОСЛІДЖЕННЯ МЕНТАЛЬНИХ РОЗЛАДІВ}

Вступ. Багато вітчизняних і закордонних експертів вивчають різні аспекти проблеми психічного здоров'я в бойових умовах, проте все ще існує велика кількість невирішених питань щодо медико-психологічних наслідків гібридної війни в Україні.

Мета статті - дослідити вплив різних шкідливих чинників в бойовому середовищі на психологічний статус і психічне здоров'я військовослужбовців і колишніх комбатантів для розробки моделі медико-психологічної допомоги.

Матеріали та методи. Матеріали дослідження було засновано на вивченні понад 200 військовослужбовців в різних умовах і стані здоров'я з використанням власних і загальноприйнятих опитувальників 3 подальшою описовою статистикою і багатовимірним аналізом даних. Було проведено бібліосемантичний, інформаційно-аналітичний порівняльний аналіз вітчизняних публікацій за останні 4 роки для узагальнення національного досвіду щодо психологічних наслідків збройного конфлікту в Україні.

Результати. Проведено ретроспективне узагальнення наявної інформації про медичні і психологічні наслідки гібридної війни за останні роки, що стосується характеристик цих наслідків на військовослужбовців і демобілізованих осіб. Проведено оцінку впливу стресових факторів бойового середовища (фізична, інформаційна, організаційна та антиципаційна) на військовослужбовців, які брали участь у військовому конфлікті, які були згруповані в два основні чинники. Виявлено особливості та структуру психічних розладів у військовослужбовців, які проходили лікування в умовах стаціонару. Розроблена модель підтримки прийняття рішень для прогнозування подальших розладів адаптації після перебування в екстремальних умовах має високий ступінь достовірності $(\mathrm{p}<0,001)$.

Висновки. Найбільший вплив на формування стресу у комбатантів надали чинники «антиципації», а також, що не менш виражені, «фізичні», «інформаційні» і «організаційні» чинники середовища. Дослідження дозволяють зробити висновок про те, що деякі 3 цих факторів істотно впливають на психоемоційний стан військовослужбовців і можуть бути згруповані в два основні чинники: 1-й - фактор негативного прогнозування майбутнього і 2-й - фактор негативного впливу фізичного середовища. Виявлено феномен перебільшення негативних відчуттів у військовослужбовців після впливу стресових факторів на 4-й місяць. Розроблена модель підтримки прийняття рішень для прогнозування подальших розладів адаптації (F43.2) після екстремальних умов доповнила розвиток сучасної моделі медико-психологічної допомоги в Збройних Силах України.

Ключові слова: модель медико-психологічної допомоги, модель підтримки прийняття рішення, психічне здоров'я, розлади адаптації, посттравматичний стресовий розлад, стресові фактори. 
Швец А.В., д-р мед. наук, старш. науч. сотр., начальник научно-исследовательского отдела специальной медицины и психофизиологии НИИ проблем военной медицины, e-mail: shvetsandro@gmail.com

Украинская военно-медицинская академия, ул. Московская, 45/1, корп. 33, г. Киев, 01015, Украина

\section{УСОВЕРШЕНСТВОВАНИЕ МОДЕЛИ МЕДИКО-ПСИХОЛОГИЧЕСКОЙ ПОМОЩИ ВОЕННОСЛУЖАЩИМ НА ОСНОВЕ ИССЛЕДОВАНИЯ МЕНТАЛЬНЫХ РАССТРОЙСТВ}

Ввведение. Многие отечественные и зарубежные эксперты изучают различные аспекты проблемы психического здоровья в боевой обстановке, однако все еще существуют многие нерешенные вопросы относительно медико-психологических последствий гибридной войны в Украине.

Цель статьи - исследовать влияние различных вредных факторов в боевой среде на психологический статус и психическое здоровье военнослужащих и бывших комбатантов для разработки модели медико-психологической помощи.

Материалы и методы. Материалы исследования были основаны на изучении более 200 военнослужащих в различных условиях и состоянии здоровья с использованием собственных и общепринятых опросников с дальнейшей описательной статистикой и многомерным анализом данных. Был проведен библиосемантический, информационно-аналитический сравнительный анализ отечественных публикаций за последние 4 года для обобщения национального опыта касательно психологических последствий вооруженного конфликта в Украине.

Результаты. Проведено ретроспективное обобщение имеющейся информации о медицинских и психологических последствиях гибридной войны за последние годы, касающееся характеристик этих последствий на военнослужащих и демобилизованных лиц. Проведена оценка воздействия стрессовых факторов боевой среды (физическая, информационная, организационная и антиципационная) на военнослужащих, участвовавших в военном конфликте. Выявлены особенности и структура психических расстройств у военнослужащих, проходивших лечение в условиях стационара. Разработанная модель поддержки принятия решений для прогнозирования дальнейших расстройств адаптации после пребывания в экстремальных условиях имеет высокую достоверность $(\mathrm{p}<0,001)$.

Выводы. Наибольшее влияние на формирование стресса у комбатантов оказали факторы «антиципации», а также, не менее выраженные, «физические», «информационные» и «организационные» факторы среды. Исследования позволяют сделать вывод о том, что некоторые из этих факторов существенно влияют на психоэмоциональное состояние военнослужащих и могут быть сгруппированы в два основных фактора: 1-й - фактор негативного прогнозирования будущего и 2-й - фактор негативного воздействия физической среды. Обнаружен феномен преувеличения негативных ощущений у военнослужащих после воздействия стрессовых факторов на 4-й месяц. Разработанная модель поддержки принятия решений для прогнозирования дальнейших расстройств адаптации (F43.2) после экстремальных условий дополнила развитие современной модели медико-психологической помощи в Вооруженных Силах Украины.

Ключевые слова: модель медико-психологической помощи, модель поддержки принятия решения, психическое здоровье, расстройства адаптации, посттравматическое стрессовое расстройство, стрессовые факторы. 